\title{
Case Report: Massive Painless Ascites in a Newly Diagnosed Case of Systemic Lupus Erythematosus
}

\author{
Salwa Ibrahim \\ Department of Internal Medicine, Cairo University, Giza, Egypt \\ Email: salwaibrahim@yahoo.co.uk \\ Received 6 July 2014; revised 5 August 2014; accepted 4 September 2014 \\ Copyright (C) 2014 by author and Scientific Research Publishing Inc. \\ This work is licensed under the Creative Commons Attribution International License (CC BY). \\ http://creativecommons.org/licenses/by/4.0/ \\ (c) (i) Open Access
}

\begin{abstract}
Systemic lupus erythematosus (SLE) is associated with inflammation of one or more of serous membranes resulting in pleural, peritoneal and pericardial effusion. Massive effusion had rarely been reported in patients with SLE and responded well to immunosuppressive therapy. We reported a case of SLE with recurrent massive ascites as the main presenting complaint with review of the available literature.
\end{abstract}

\section{Keywords}

Systemic Lupus Erythematosus, Serositis, Ascetis

\section{Introduction}

Systemic lupus erythematosus (SLE) is an autoimmune disease characterized by involvement of various organs. Serositis is frequently observed in these patients. However, massive ascites is rarely reported and has a gradual onset and responds to immunosuppressive therapy. We described a case of a 32-year-old female who presented with massive ascites and fever as main features of SLE on admission.

\section{Case History}

A 32-year-old female, married and has 4 children was admitted to our hospital with progressive painless abdominal distension of 4 months duration. The condition was associated with intermittent fever reaching $38.5^{\circ} \mathrm{C}$ at night. There was no associated sore throat, abdominal pain, or dysuria during her hospital course. Two years before admission, she was told to have rheumatoid arthritis as she had recurrent pain affecting small joints of the hands, shoulder and elbow joints with morning stiffness for more than an hour. She was treated with lefulona- 
mide with partial improvement of her pain. No history of malar rash, discoid rash, or photosensitivity.

On examination, she was febrile with temperature range $37.5^{\circ} \mathrm{C}-38.2^{\circ} \mathrm{C}$. BP $110 / 70$ and pulse was $100 /$ minute. She was pale, JVP was elevated, apex was in the $5^{\text {th }}$ left intercostal space midclavicular line with normal heart sounds. Chest examination was normal apart from limited expansion on right lung base. Abdominal examination revealed massive ascites. There was mild bilateral pitting ankle swelling. Joint and neurological examination was unremarkable.

Complete blood count showed hemoglobin was $7.4 \mathrm{~g} / \mathrm{dl}$, RBCs $2.78 \times 10$, TLC $3.9 \times 10$ and platelet count $139 \times 10$. ESR was $1101^{\text {st }}$ hour and CRP $95 \mathrm{mg} / \mathrm{dl}$. BUN was $127 \mathrm{mg} / \mathrm{dl}$, serum creatinine $2.5 \mathrm{mg} / \mathrm{dl}$, serum albumin $3.1 \mathrm{mg} / \mathrm{dl}, 24$ hour protein in urine was $0.25 \mathrm{~g}$. Tuberculin test was negative, HBsAg was negative, and HCV antibodies were negative. Ascetic fluid examination revealed clear yellow fluid with SAAG gradient 1.1. Bacterial and mycobacterial cultures of the fluid revealed no growth. C3 was $39 \mathrm{mg} / \mathrm{dl}$ (normal range $90-180$ $\mathrm{mg} / \mathrm{dl}$ ) and C4 was $8 \mathrm{mg} / \mathrm{dl}$ (normal range $10-40 \mathrm{mg} / \mathrm{dl}$ ). Antinuclear and anti double stranded DNA antibodies were positive.

Chest X ray showed blunting of both costophrenic angles by minimal effusion. X ray of hands revealed no abnormality detected. Abdominal ultrasonography showed normal sized liver, spleen and grade I pathological kidneys and massive ascites with adhesions. Transvaginal ultrasonography showed massive ascites in Douglas pouch with periovarian adhesions. CT abdomen revealed massive pelviabdominal free ascites with minimal bilateral pleural effusions

\section{Renal Biopsy}

Twenty two glomeruli presented; six of which are obsolescent. The tufts show variable degrees of mesangial matrix expansion associated with irregular thickening of GBM. Five glomeruli show segmented sclerosis (mainly in subcapsular area). Single glomerulus showed wire loop formation and hyaline thrombi. The tubules show marked hydropic degeneration and some contain hyaline casts. The arteries and arterioles are thickened. JGA is unremarkable (Figure 1).

\section{Diagnosis}

Lupus nephritis: membranoprolilerative GN (TYPE VI) with secondary focal segmental sclerosis (active/ chronic).

\section{Hospital Course}

The patient was diagnosed as SLE with lupus nephritis and serositis (massive ascites). She fulfilled 4/12 criteria of $4 / 11$ and $3 / 6$ of the clinical and immunological criteria of SLE [1]. We started her on $60 \mathrm{mg} /$ day prednisolone and IV monthly cyclophosphamide together with hydroxychloroquine $200 \mathrm{mg}$ twice daily. After five doses of IV cyclophosphamide, her abdominal girth decreased from $100 \mathrm{~cm}$ to $80 \mathrm{~cm}$ and her weight decreased from 60

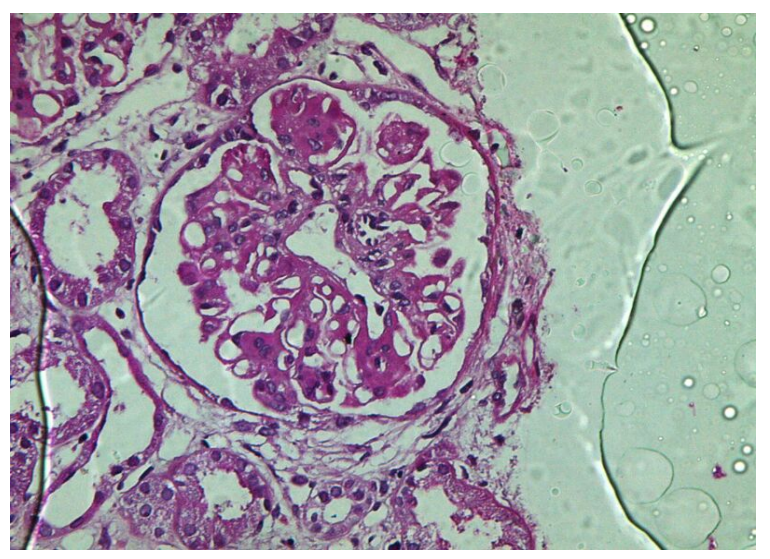

(a)

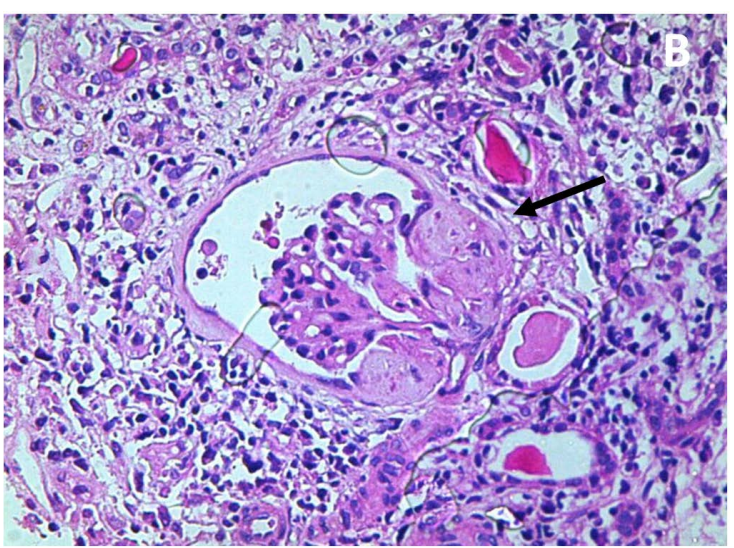

(b)

Figure 1. Showed mesangial matrix expansion and irregular thickening of the GBM (a) and focal segmental scarring (b). 
to $53 \mathrm{~kg}$. hemoglobin level increased from 7.2 gram $/ \mathrm{dl}$ to $10.2 \mathrm{~g} / \mathrm{dl}$ and the ESR decreased $150 \mathrm{~mm} / \mathrm{h}$ to 40 $\mathrm{mm} / \mathrm{h}$. Serum creatinine decreased from $2.3 \mathrm{mg} / \mathrm{dl}$ to $1.2 \mathrm{mg} / \mathrm{dl}$ and serum albumin increased to $3.6 \mathrm{mg} / \mathrm{dl}$. She is afebrile and had no joint pains.

\section{Discussion}

It has been postulated that ascites occurs in SLE secondary to cardiac, hepatic or renal disorders. However, the ascites in this patient was due to serositis and resolved completely on corticosteroid and cyclophosphamide therapy and did not recur. Serum albumin was $3.1 \mathrm{mg} / \mathrm{dl}$ and the 24-hour protein was $0.25 \mathrm{~g}$ and both cannot explain the existing massive ascites despite the presence of minimal ankle edema and the lack of facial swelling and the puffiness of eye lids. CRP was markedly increased $(95 \mathrm{mg} / \mathrm{dl})$ and this was suggestive of active serositis.

Peritoneal involvement has been found in two thirds of patients with SLE who undergo necropsy [2] though it is detected clinically only in $4 \%$ [3] to $16 \%$ [4] of them. Ascites may present acutely or chronically, with or without pain, and it may be due to lupus peritonitis [5], visceral infarction [6], congestive heart failure [6], constrictive pericarditis [6], nephrotic syndrome [4], Budd-Chiari syndrome [7], protein losing enteropathy [8], and acute pancreatitis [9].

The pathogenesis of chronic lupus peritonitis with ascites is not entirely clear. Deposition of immune complexes on the peritoneum may explain it [4]. Mier et al., 1985 reported two cases of SLE with tense recurring ascites as the main clinical problem on admission [10]. Kaklamanis et al., 1991 reported a case of SLE who developed unexplained ascites several months before flaring of her disease with polyserositis and glomerulonephritis [11]. Soysal et al. 2013 reported a rare case of hydrothorax and chylous ascites in SLE case [12]. Weinstein et al. 2014 reported a case of rapid onset of massive ascites as the initial presentation of systemic lupus erythematosus [13].

Lupus serositis usually responds well to immunosuppressant including pulse methylprednisone and cyclophosphamide [10]-[14]. Hammami et al. 2014 reported a case of massive painful ascites in a 77-year-old SLE female who was cured with hydroxychloroquine $200 \mathrm{mg}$ daily [15].

\section{Conclusion}

In conclusion, we described a case of SLE who presented with persistent massive unexplained ascites that was not explained by the degree of proteinuria, with good response to immunosuppressive therapy.

\section{References}

[1] Petri, M., Orbai, A.M., Alarcon, G.S., et al. (2012) Derivation and Validation of the Systemic Lupus International Collaborating Clinics Classification Criteria for Systemic Lupus Erythematosus. Arthritis Rheumatology, 64, 2677-2686. http://dx.doi.org/10.1002/art.34473

[2] Ropes, M.W. (1976) Characteristics, Manifestations and Pathologic Findings. In: Ropes, M.W., Ed., Systemic Lupus Erythematosus, Harvard University Press, Cambridge, 40-41.

[3] Rothfield, N. (1985) Clinical Features of Systemic Lupus Erythematosus. In: Kelley, W.N., Harris Jr., E.D., Ruddy, S. and Sledge, C.B., Eds., Textbook of Rheumatology, 2nd Edition, Saunders, Philadelphia, 1070-1097.

[4] Schousboe, J.T., Koch, A.E. and Chang, R.W. (1988) Chronic Lupus Peritonitis with Ascites: Review of the Literature with a Case Report. Seminars in Arthritis and Rheumatism, 18, 121-126. http://dx.doi.org/10.1016/0049-0172(88)90004-2

[5] Doherty, N.E. and Sigel, R.Y. (1985) Cardiovascular Manifestations of Systemic Lupus Erythematosus. American Heart Journal, 110, 1257-1265. http://dx.doi.org/10.1016/0002-8703(85)90023-7

[6] Jacobsen, E.J. and Reza, M.J. (1978) Constrictive Pericarditis and SLE. Arthritis Rheumatology, 21, $972-974$.

[7] Averbuch, M. and Levo, Y. (1986) Budd-Chiari Syndrome as the Major Complication of Systemic Lupus Erythematosus with the Lupus Anticoagulant. Annals of the Rheumatic Diseases, 45, 435-437. http://dx.doi.org/10.1136/ard.45.5.435

[8] Trentham, D.E. and Masi, A.T. (1976) Systemic Lupus Erythematosus with a Protein Losing Enteropathy. JAMA, 236, 287-288. http://dx.doi.org/10.1001/jama.1976.03270030041027

[9] Pollack, V.E., Grove, W.J. and Kark, R.M. (1958) Systemic Lupus Erythematosus Simulating Acute Surgical Condition of the Abdomen. New England Journal of Medicine, 254, 258-265.

http://dx.doi.org/10.1056/NEJM195808072590602 
[10] Mier, A. and Weir, W. (1985) Ascites in Systemic Lupus Erythematosus. Annals of the Rheumatic Diseases, 44, 778779. http://dx.doi.org/10.1136/ard.44.11.778

[11] Kaklamanis, P., Vayopoulos, G., Stamatelos, G., Dadinas, G. and Tsokos, G. (1991) Chronic Lupus Peritonitis with Ascites. Annals of the Rheumatic Diseases, 50, 176-177. http://dx.doi.org/10.1136/ard.50.3.176

[12] Soysal, D., Turan, S., Ozmen, M., et al. (2013) A Rare Case of Systemic Lupus Erythematosus with Chylous Ascites and Chylothorax. Case Reports in Rheumatology, 2013, Article ID: 797696.

[13] Weinstein, P. and Noyer, C. (2000) Rapid Onset of Massive Ascites as the Initial Presentation of Systemic Lupus Erythematosus. The American Journal of Gastroenterology, 95, 302-303. http://dx.doi.org/10.1111/j.1572-0241.2000.01558.x

[14] Andouh, A., Fujiyama, Y., Kitamura, S., et al. (1997) Acute Lupus Peritonitis Successfully Treated with Steroid Pulse Therapy. Journal of Gastroenterology, 32, 654-657. http://dx.doi.org/10.1007/BF02934116

[15] Hammami, S., Bdioui, F., Ouaz, A., et al. (2014) Successful Treatment of Massive Ascites Due to Lupus Peritonitis with Hydroxychloroquine in Old-Onset Lupus Erythematosus. The Pan African Medical Journal, 18, 165.

http://dx.doi.org/10.11604/pamj.2014.18.165.2080 
Scientific Research Publishing (SCIRP) is one of the largest Open Access journal publishers. It is currently publishing more than 200 open access, online, peer-reviewed journals covering a wide range of academic disciplines. SCIRP serves the worldwide academic communities and contributes to the progress and application of science with its publication.

Other selected journals from SCIRP are listed as below. Submit your manuscript to us via either submit@scirp.org or Online Submission Portal.
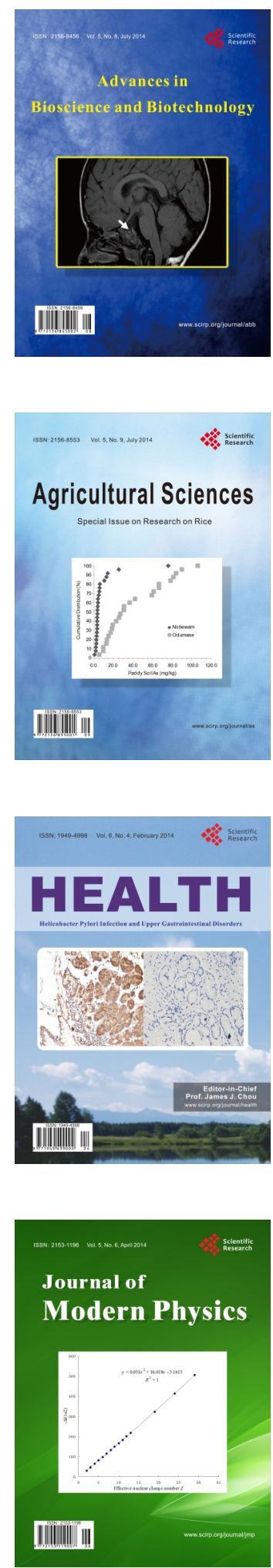
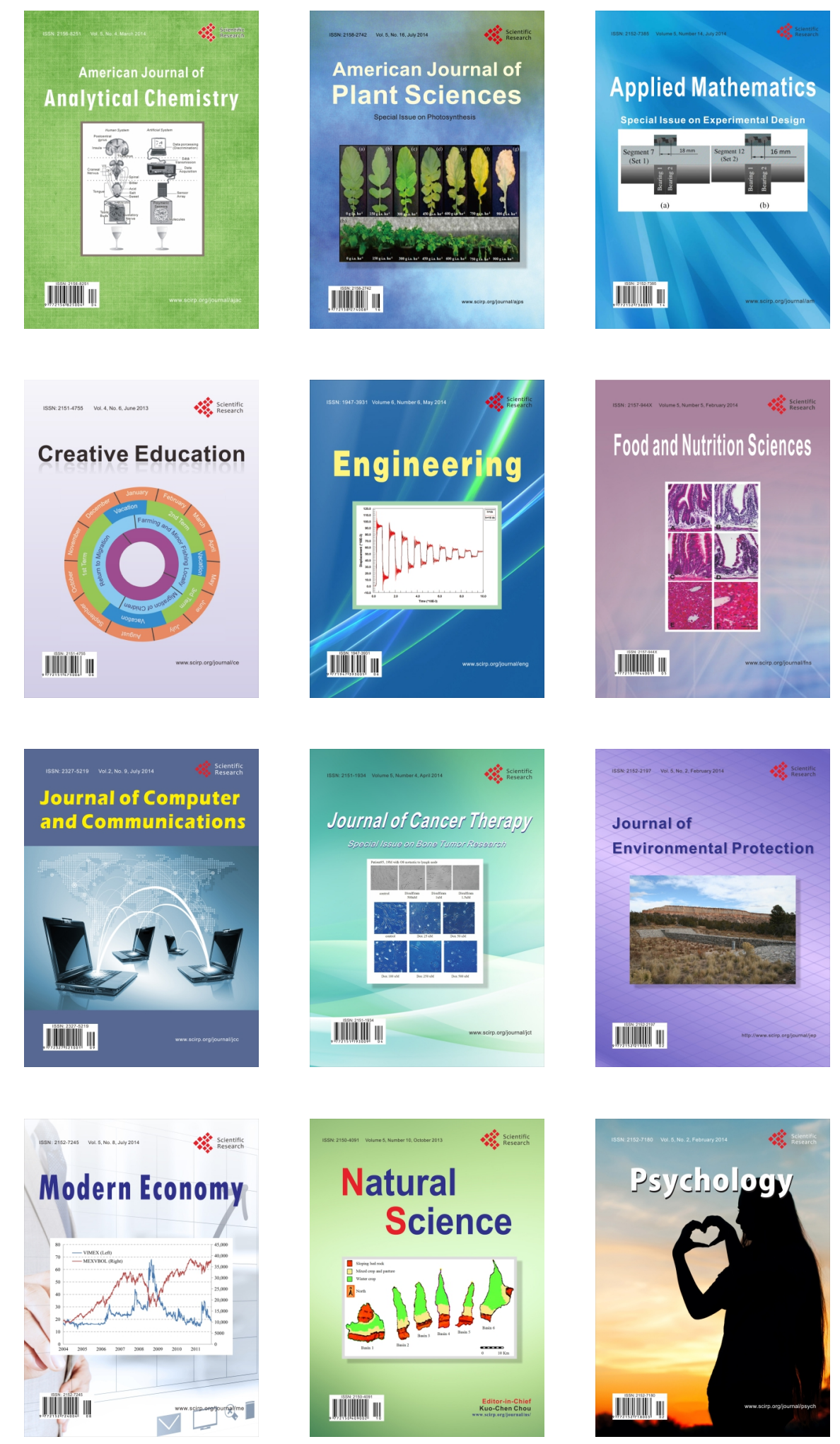